\title{
The Pandemic and the Transformation of Liberal International Order
}

\author{
Qingming Huang ${ }^{1}$ (B)
}

Accepted: 11 September 2020 / Published online: 16 October 2020

(C) Journal of Chinese Political Science/Association of Chinese Political Studies 2020

\begin{abstract}
In 2018, 43 leading International Relations scholars in the United States signed a public statement in support of an urgent call to preserve the current international order, triggering heated scholarly debates. The idealized form of the liberal international order was criticized by many scholars for its chronic problems, including the contradictions between proclaimed liberal values and illiberal behaviors, the inability to reform its institutional pillars to accommodate the diverse group of emerging powers, and the tensions between the defenders of this order and its challengers. These problems became fully exposed under the external shock caused by the coronavirus pandemic. As the coronavirus spreads globally and disrupts the world's political, economic, and social fabric, several forces that have gained momentum and strength during the last decade are now converging as a formidable force that may reconfigure the postpandemic international order. This paper addresses three significant challenges to the foundations of the current liberal order: (1) the entrenchment of authoritarianism, characterized by authoritarian resilience, autocratization, and the consolidation of competing authoritarian political-economic models; (2) the exacerbation of nationalism enabled by nationalist and populist politicians; and (3) the intensified competition among major powers. China has played mixed roles in the process of reconfiguring the current order. It challenges the mythologized liberal international order and exposes the contradictions in the dominant Western model, while promoting an alternative hybrid political-economic model. The shock brought by the pandemic has provided ample opportunities for China to extend its networks and expand international space for its model.
\end{abstract}

Keywords Liberal international order · authoritarianism · nationalism · pandemic · transformation

Qingming Huang

galiqm@ufl.edu

1 Department of Political Science, University of Florida, Gainesville FL 32603 USA 


\section{Introduction}

Two years ago, 43 leading International Relations (IR) scholars in the United States signed a public statement in support of an urgent call to preserve the current international order, ${ }^{1}$ triggering heated debates among IR scholars. In the statement, prominent IR scholars reiterated the benefits provided by the liberal international order after the Second World War, including economic stability and prosperity, as well as international security and peace. They warned against the potential destruction that American President Donald Trump would bring and the chaos that could ensue in the international arena.

Conversely, other scholars noted the limitations of the often-idealized liberal international order and the troubles associated with its major institutional pillars $[1,2]$. Critics suggest that, by treating the potential change in the current international order as a crisis, the order's defenders might reflect an entrenched Western-centric - and especially U.S.-centric - view of IR, ignoring the chronic problems rooted in such an idealized order. Problems that have received increased scrutiny in recent years include (1) contradictions between proclaimed liberal values and illiberal behaviors [1, 2]; (2) an inability to reform the order's institutional pillars to accommodate the diverse group of emerging powers [3-5]; and (3) tensions between the defenders and challengers of this order [6].

Notwithstanding their distinct positions in pre-COVID-19 debates, there is one point on which they might agree. That is, the external shock of the novel coronavirus pandemic has generated significant pressures on the current liberal international order. The pandemic has reinvigorated debates about maintaining or restructuring the current order, and the directions of change [7]. This paper joins the timely scholarly debates about the crisis and future of liberal international order by analyzing the changing dynamics in both domestic and global contexts during the pandemic. Specifically, this paper addresses the following questions: What are the underlying tensions of the current liberal order and the sources of change to this order? How has the pandemic changed the dynamics of the current order and destabilized its major foundations? What are the implications of these changes and the roles played by challengers such as China?

The current liberal international order rests upon at least three crucial foundations: (1) the liberal ideology that emphasizes democratic values and norms; (2) the principle of multilateralism, which emphasizes international cooperation and management of international affairs through multilateral institutions; and (3) a group of defenders with common goals and shared commitment to preserve liberal values, norms, principles, and institutions. In this paper, I argue that, these core foundational components are under attack from all sides during the coronavirus pandemic. As the coronavirus spreads globally and disrupts the world's political, economic, and social fabric, several forces that have gained momentum and strength during the last decade are now converging as a formidable force during the pandemic. The convergence of these

\footnotetext{
1 "Why We Should Preserve International Institutions and Order," a public statement signed by prominent IR scholars and published in New York Times on July 23, 2018, available at scholar.princeton.edu/hvmilner/ news/why-we-should-preserve-international-institutions-and-order.
} 
forces not only exposes the underlying tensions of current order but will also reconfigure the post-pandemic global order.

In this paper, I focus on three significant material and ideational forces currently shaking the foundations of the existing liberal order. These mutually reinforcing domestic and international sources of change are generating immense pressure to transform the current order. First, the entrenchment of authoritarianism is eroding the popularity of liberal ideology and altering the regime landscape worldwide. This first force is characterized by authoritarian resilience, autocratization, and the consolidation of competing authoritarian political-economic models led by China and other challengers. Second, the exacerbation of nationalism, enabled by nationalist and populist politicians, has damaged the popularity and authority of established Westerndominated international institutions that buttress multilateralism and the seemingly unstoppable forces of globalization promoted by the liberal order. The surge of nationalism also pushes states to make choices that are most aligned with their national interests, from both material and ideological perspectives. Third, the pandemic has intensified the competition among major powers, including the retreating global leader (the United States), the weakening coalition (the European Union), and the rising but besieged challenger (China). The myth about an ideal and cohesive liberal order, forged by Western solidarity and a shared sense of purpose and righteousness, has been debunked during the pandemic, leaving space for challengers like China to exploit the internal division and fragmentation within the West and extend its influence globally.

This paper begins by examining the literature on liberal international order and discusses the three major foundations of this order. It highlights the contrast between the ideal and the reality of liberal international order, juxtaposes the defenders and challengers' perspectives, and illustrates the underlying tensions of current order. In the next section, this paper analyzes how multiple forces during the pandemic are shaking the major foundations of the current international order and the implications of each of these changes. This paper concludes with the discussion of China's mixed roles and position in a multiplex international order with competing political-economic models.

\section{Literature Review}

\section{Is Liberal International Order in Crisis?}

In the weeks following the public statement by IR scholars, more than 570 scholars joined the efforts in defending the post-war liberal international order. Most scholars agree that this order has produced unprecedented peace and prosperity, and U.S. leadership is essential for its success. The United States has paid a large portion of the costs of this order but has also benefited substantially [8]. According to Ikenberry, the U.S.-led post-war liberal international order is "a hierarchical order with liberal characteristics" [9: 7]. On the one hand, the United States has dominated the order and served as the leading provider of rule and stability in this order. On the other hand, the order has been built on the liberal principles of governance supported by a wide array of multilateral rules and institutions. In general, the order is "relatively open, rulebased, and progressive" [9: 2]. More specifically, it has been "organized around 
economic openness, multilateral institutions, security cooperation and democratic solidarity" and has undergone significant expansion after the end of the Cold War [10: 7].

The U.S.-led liberal international order was at its zenith after the downfall of the ideological and geopolitical rival - the Soviet Union - and the end of the Cold War. According to the existing literature, the liberal international order has been solidly supported by at least three major foundations. First, in terms of ideology, it is liberal at its core. The collapse of communism and the expansion of democracy across several regions of the world was seen as the triumphant moment for Western liberal democracies $[10,11]$. Liberal ideology that emphasizes democratic values and norms has not only been consolidated in Western countries but also proliferated to countries previously outside the boundary of the "free world". With the expansion of the "free world", liberal internationalism offers a set of ideas and agendas that liberal democracies use to organize the world based on their vision of "an open, loosely rules-based and progressively oriented international order" [10]. Universal values, such as the rule of law, respect for countries' sovereignty and territorial integrity, and protection of human rights, were promoted globally in an open-to-all and voluntary way. With the help of hard power, the ideals embraced by democracies are to "be applied to the entire planet", shaping the world in a single kind of order, or "whole" [12]. In other words, alternative ideologies such as authoritarianism and exclusionary nationalism are to be cast aside to further expand the international space for liberal ideology.

Second, the U.S.-led liberal international order has been based on the principle of multilateralism, which emphasizes international cooperation and management of international affairs through multilateral institutions. As Ruggie describes, multilateralism is an institutional form that "coordinates behavior among three or more states on the basis of generalized principles of conduct" [13: 14]. Multilateralism served as the foundational principle for the American post-war planners to reconstruct the international order [13: 25]. The international institutions constructed under the principle of multilateralism remain robust and adaptive over time and play an essential role in sustaining the liberal international order [14]. They act as "agents of norm construction and normative change" that could regulate and transform state behavior. They not only help to define, promote, and legitimize certain global norms but also make the transformation of international order more legitimate and peaceful [15]. Multilateral institutions and related norms helped stabilize the international system after the sudden collapse of the Soviet Union [13: 3]. Since the end of the Cold War, rather than abandoning or weakening their commitment to multilateral institutions such as the North Atlantic Treaty Organization (NATO) and the European Union (EU), states have invested more material and reputational resources into these institutions to realize their interests and gain from the order [16]. Moreover, along with the expansion of liberal international order and the integration of more countries into the global capitalist system, multilateral institutions and the policies forged within such institutions have enabled and promoted both political and economic globalization.

Lastly, the post-war liberal international order has been guarded by a group of defenders with common goals and shared commitment to preserve liberal values, norms, principles, and institutions. The dominance of the United States with economic and military superiority has helped ensure "an international system of relative peace and security," and "created and enforced the rules of a liberal international economic order" [17]. Under the auspice of this hegemonic superpower and with the support from 
other Western powers, international institutions that weave the liberal international order together are able to sustain their vitality and respond to the changing international environment $[18,19]$. The United States has become a leading provider of a wide array of public goods, upholding rules and institutions, facilitating security cooperation, managing global economy, and promoting shared values and norms. As Ikenberry puts it, during the Cold War, the American liberal hegemony, as a distinctive type of international order, was further "'fused' to the evolving and deepening postwar liberal order" [10: 15]. In other words, the United States is deeply embedded in the current order. The order is essentially structured around this dominant power and its democratic allies and clients. The United States not only serves as the primary provider of global public goods but also as the leader and unifier of the liberal order. Moreover, the group of defenders rallying behind the United States have shared ideology, interest, and commitment to sustain a cohesive liberal order.

Considering the liberal international order in its idealized form, it seems to be trapped in a deepening crisis. The first sign of crisis is evident in the decline of the United States and its gradual disengagement from international affairs, especially after Trump took office. During his first term, Trump withdrew from the Paris Accord; the Trans-Pacific Partnership; the United Nations Educational, Scientific and Cultural Organization (UNESCO); and the United Nations Human Rights Council (UNHRC). Moreover, he has generated tensions with long-term allies in Europe and tarnished the image of the liberal order. As expressed by Trump in his speech at the UN General Assembly, "America will always choose independence and cooperation over global governance, control, and domination" [20]. It seems that the United States is stepping back from its role as a world leader. Some scholars lament that, without a broader vision as defender of the free world, and with a new focus on pursuing narrow national interest, Trump's America is abandoning its "global leadership" as the "long-time champion" of the liberal international order [21]. Even worse, Trump has launched a direct attack on this order - the system of multilateral trade and alliances that the United States built to serve its interests and attract others to its "way of life" [22]. Cooley and Nexon's assessment further demonstrates that the unravelling of American hegemony was already underway before Trump's presidency. Trump only sped up America's retreat in the liberal international order [23]. Moreover, the doubt cast on America's leadership by its allies in Europe, the loss of "a vision of how the world is supposed to work", and the challenge from internal fragmentation all contributed to "the eclipse of the West" [24].

The second sign of crisis is the rise of China and Russia in the international arena. Scholars had already sounded alarms before Trump took office. Besides their military power, challengers like China and Russia threaten the existing liberal order by disrupting it with their own political systems, interests, and ideologies [25]. According to Stephens, the rise of revisionist powers, including China, Russia, and Iran, have posed serious challenges to America's claims on "both the goodness and the success of the liberal-democratic model". As these powers become increasingly assertive and ambitious, the U.S.-led order is in deep trouble [26]. Moreover, a larger group of challengers - the emerging economies in the BRICS countries (Brazil, Russia, India, China, and South Africa) - are increasingly undermining the Western dominance, especially after the financial crisis in $2008[5,6]$. In particular, in recent years, China has moved from a reformist of the liberal international order to a revisionist that seeks 
to establish "new systems of governance and international cooperation" [27: 14]. The factors behind this change include China's renewed self-confidence and awareness of a greater role in global arena, the reluctance of the West to reform, the weakening of the United States after the 2008 financial crisis, and the dominant powers' alienation of developing countries [27]. Although scholars disagree on the extent of disruption that China may bring to the liberal international order, there are evident concerns that the U.S.-led order may be replaced by a new one dominated by China [26-28].

To many Western scholars, these two trends - the retreat of the United States and the rise of powerful challengers - are indeed worrisome, as reflected in their warnings of a "new global disorder" [25] or "a descent into the chaos of a world without effective institutions that encourage and organize cooperation." " In Stephens's words, the only alternative to Pax Americana would be global disorder [26]. And it is likely to bring about "a highly competitive international environment" that may result in "unprecedented global calamity" [29]. The main problem with this line of argument is that, the liberal international order discussed by these scholars tends to mix its normative aspect with the observed reality. Their emphasis on the normative or idealized aspect of the liberal international order often leads to the assumption that this order is a unitary and cohesive whole that needs to be preserved in its original form, including perpetuating the American dominance. As such, any existing alternatives or emerging experiments are considered as disruptive to the order or sowing the seeds of disorder. In particular, an illiberal order would be considered as the opposite of all the good things brought together in the liberal order. It will be "politically and economically divided and closed, authoritarian, uncooperative, coercive, and disrespectful of rules and norms" [30: 5].

However, to understand the depth of the crisis of liberal international order, it is necessary to examine the differences between the normative order and the empirically observed order. As Rosenau notes, to be insensitive to their distinctions will "run the risk of either clouding sound analysis with preferred outcomes or confounding preferred outcomes with empirically faulty recommendations" [31: 10]. Scholars need to distinguish observations of the reality of the international order from judgments and visions of such order. In Buzan's words, adopting the normative aspect of such a concept could be seen as an effort to consider what is possible and advocate what is desirable [32: 300]. However, it is necessary to acknowledge that the reality on the ground may not approximate the desired ideal. Regarding the current liberal international order, its advocates often offer a narrow and highly selective view of history. They tend to ignore aspects of coercion, violence, and instability in the post-war era, while emphasizing the order's unwavering support for democracy, freedom, and human rights [1]. This tendency has led to what Allison calls the "myth of the liberal order". In his words, the liberal international order is essentially "an imagined past in which the United States molded the world in its image" [33]. Moreover, the nostalgic view of the liberal order is ahistorical as it ignores the process of ordering that was marked by episodes of violence, coercion, and resistance, as well as the imperial prerogatives of the United States that had often disregarded rules and accommodated illiberal forces [30].

Beneath the surface of "stability" and "peace", the liberal international order is rife with tensions, the first of which comes from the competition between different

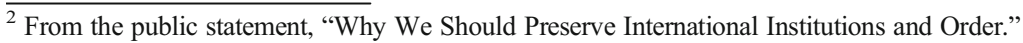


political-economic models. That is, the liberal model, supported by dominant Western powers, is challenged by the so-called illiberal models promoted by major challengers like China. These models are by no means pure in their forms and practices. There are evident contradictions within each model. Just as the liberal model has elements of coercion and violence, the illiberal model also contains elements of cooperation and rule. The second tension arises between states seeking to assert their agency against the seemingly inexorable and homogenizing forces of globalization promoted by the liberal order. States refuse to be hollowed out by the globalizing forces and seek to assert their authority and legitimacy both within their territorial boundaries and in transnational processes. In the context of external shock and rising nationalism, states would prioritize their national interests and make choices that are most aligned with their material and ideological preferences. Finally, the third tension lies between the defenders and challengers of the existing order. Countries with increasing military and economic power may seek to transform the current international order to better reflect their own ideologies and serve their interests. The competition between major powers could be intensified by triggers like financial crisis or pandemic crisis.

\section{The Challengers' Perspectives}

If the existing order rests upon widening economic discrepancies among actors, there will be growing pressure for change. If the material conditions, including the distribution of resources among actors, undergo substantial change, the current arrangement could potentially reconfigure, leading to a breakdown or restructuring of prevailing order [31]. Moreover, the image presented by the liberal world has been and will continue to be questioned by the emerging powers, further deepening the ideological divisions between them. The rising powers could also promote their images and profiles globally, provide political, economic and military goods to their clients and partners around the world, and rally support for their alternative political-economic models in the global arena. In other words, they compete with each other to sell their models in the global market of economic resources, security, aid, and ideology.

By highlighting the influence of ideas on the international arena, the constructivists' account of international relations has filled in the gap left by the liberals and realists and it offers important tools for scholars to analyze the changing dynamic of the international order. According to the constructivists, ideas can generate identities and interests, help states and other actors find common solutions to problems, and shape their understandings of threats and expectations of the others' behavior [34]. The influence of ideas can work through at least three pathways: Beliefs can serve as roadmaps for decision-making; shared ideas can serve as focal points in facilitating cooperation; and ideas, enhanced by the international norms and rules and embodied in the institutional frameworks, can constrain the actors' choices [14]. Being embedded in the dense networks of international social relations, states could be "socialized to want certain things" [35: 2].

In other words, states and other actors can choose to play the game in the current order, respond to the changing environments, or develop their own rules of the game to suit their purposes. The circulation of different beliefs and ideas about how the world should be organized has turned the international arena into a contested field. Instead of conforming to the expectations by dominant Western countries, powerful challengers 
may push for more space for multiple models of governance in the international order. The convergence of beliefs and ideas can reinforce the popular appeal of certain models and could serve as focal points for different actors to coordinate their actions and reshape the international norms. Moreover, the creation and extension of international social networks by new institutional platforms or linkages can facilitate socialization between states and encourage state leaders to "want certain things", which could include access to alternative sources of economic power, security, aid or ideology.

The rising challengers have benefited from the Western-dominated order. But they also challenge the mythologized liberal international order and expose the contradictions in the dominant Western model which often needs to reconcile its proclaimed liberal values with illiberal behaviors. The idealized image of liberal international order does not always align with reality, especially in the case of the order's most powerful leader. As Strange [36: 573] observed, there was a clear gap between America's rhetoric in preaching liberalism, internationalism, and multilateral decision-making, and its "inconsistent, fickle, and unpredictable" conduct of foreign policy. Other scholars have noted that, there were plenty of illiberal behaviors by the countries that proclaimed liberal values. For instance, the United States supported authoritarian rulers throughout the Cold War, and afterwards; it also dismantled the Bretton Woods, and invaded Afghanistan and Iraq, etc. [1,37]. Some scholars suggest that the so-called liberal international order has "never existed". Even after the end of the Cold War when liberal principles were promulgated to more countries, the liberal international order only "got closer to having a liberal quality but never quite passed the threshold" [38].

By treating the potential change in the current international order as a crisis, many prominent scholars reveal their Western-centric, and especially the U.S.-centric, views of IR. As Hobson points out, many IR scholars continue to reproduce the discourse of power through their own works. For instance, one prominent scholar who signed the public statement has argued on another occasion that, humanitarian interventionism and structural adjustment programs are essential for keeping the non-Western world on track toward Western-style liberal capitalism and democracy. Without interventions by the West, these countries are denied the opportunities and "privileges" to imitate the advanced Western model [39: 17-18]. This argument echoes the tone in the public statement, which emphasizes how the existing order has served the United States and its allies well for more than seven decades and brought unprecedented levels of prosperity and peace to the world. ${ }^{3}$ In the meantime, there is no mention of what kind of reform and change is needed.

In the challengers' eyes, such reform has been delayed for too long. The pressure on the current international order began building during the financial crisis in 2008. Before that, advanced countries in the Group of Seven (G7) promised to give more voices to emerging economies in international institutions such as the International Monetary Fund (IMF). But they failed to deliver on promised reforms. Instead of embracing "the dawn of a new era of multilateralism", the world is witnessing "the last gasp of an oldfashioned concert of great powers" [5: 51]. Another example is the World Bank, which Weaver [4: 3] illustrates as mired in "bureaucratic 'pathologies', dysfunctions, and legitimacy crises", unable to make substantive changes in its structures, policies,

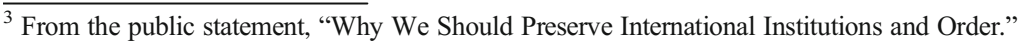


ideologies, and behaviors. As a result, a new order less reliant on these traditional international institutions, such as the IMF and the World Bank, may be emerging.

Similarly, Stephen argues that existing international institutions are often too "sticky" to adapt to the new distribution of power and the preferences brought by the diverse group of emerging powers. The challenges from the BRICS countries may bring about an order that is "strongly contested, less universal, less liberal, and more fragmented" [6: 484]. Ikenberry notes that the old U.S.-led order may be in the "crisis of transition" whereby "a new configuration of global power, new coalitions of states, new governance institutions" will emerge [10: 8]. As Acharya observes, a key driving factor to this fragmentation is "the outdated system of privilege enjoyed by the Western countries and their abuse of existing rules and norms and resistance to the lack of reform of multilateral institutions" [3: 457]. In a post-hegemonic multiplex world, the United States must relinquish certain privileges and share its power and authority with emerging powers [40]. However, the United States has already shown its reluctance to share its power and privileges, despite its gradual retreat from global leadership.

In a white paper that focuses on the relation between China and the world, China criticizes the theory that assumes China will seek hegemony as it gets stronger and pose serious threat to the world. The report points out that this interpretation is driven by "cognitive misunderstanding, deep-rooted prejudice, a psychological imbalance brought about by the prospect of falling power, and deliberate distortions by vested interests" [41]. One the one hand, the report emphasizes China's contribution to the world economy as "a stabilizing force and power source" and "an important promoter of global openness and a dynamic market". It further states that, China has benefited from the international community and in return provides it with more and better public goods. On the other hand, the report points out the dangers of blindly copying or being forced to adopt the Western model, which had led to "social unrest, economic crisis, governance paralysis, and even endless civil war". The report proposes to build "a global community of shared future" that opposes "the law of the jungle, power politics and hegemonism" [41].

As stated in the report, in a new model of international relations, there should be 1) mutual respect based on equality among all countries and respect of other's political systems and developmental paths; 2) equal right and equal access to opportunities and proper balancing of national interests and contribution to international community; and 3) mutually beneficial cooperation. More importantly, the world should uphold the international order or global governance system with the United Nations as its core, rather than the United States. According to the report, China has no intention of replacing the United States. But the United States also needs to "abandon the Cold War mentality, and develop a proper understanding of itself, China, and the world", adapting to the development and prosperity of other countries and living in harmony with them [41]. If it fails to do so and tries to maintain its strength by suppressing other countries, any serious strategic miscalculation may lead to conflict and confrontation between major countries.

Since the financial crisis of 2008, tensions within the existing liberal international order have grown, especially between the defenders and challengers of the existing order and between different political-economic models. The external shock caused by the ongoing pandemic exacerbates the tensions and accelerates the reshuffling of the existing order. As the pandemic continues, several material and ideational forces, 
including the entrenchment of authoritarianism, the exacerbation of nationalism, and the renewed competition between the major powers, have converged to reconfigure the international order. Before the pandemic, the international arena had already turned into a contested field for competing models of governance in the international order. The pandemic has intensified this competition. The entrenchment of authoritarianism allows the consolidation of alternative political-economic models proposed and promoted by powerful challengers vis-à-vis the liberal model supported and dominated by Western powers. The exacerbation of nationalism not only chips away the authority and legitimacy of established Western-dominated international institutions but also pushes states to make choices that are most aligned with their national interests, from both material and ideological perspectives. Moreover, these two forces have laid the new ground from major actors, including the United States, the European Union, and China, to engage in a renewed great power competition in the pandemic era. The myth about an ideal and cohesive liberal order, forged by Western solidarity and a shared sense of purpose and righteousness, has been further debunked during the pandemic, leaving space for challengers like China to exploit the internal division and fragmentation within the West and extend its influence globally. In the following section, I examine these three sources of change and discuss how they may have changed the dynamics of the current order and shaken its foundations.

\section{Sources of Change during the Pandemic}

\section{The Entrenchment of Authoritarianism}

The first challenge to the current liberal order comes from the entrenchment of authoritarianism during the pandemic, as characterized by authoritarian resilience, autocratization, ${ }^{4}$ and the consolidation of competing political-economic models built by leading authoritarian countries. As numerous democracies test the boundaries of freedom and control, authoritarian leaders across the world exploit the coronavirus crisis to tighten control over their people even further. The sweeping measures and institutional arrangements utilized by these leaders to combat the virus will leave significant legacies on both domestic politics and foreign policies. Interpreted in the path-dependence framework, the decisions made at certain "formative moments or conjunctures" can influence the long-term institutional trajectories. These institutions can be "sticky" and resistant to changes [43]. Moreover, riding the wave of autocratization, leading authoritarian countries like China have consolidated their competing political-economic models vis-à-vis the Western-dominated model. As increasingly powerful and ambitious patrons in the global arena, they have provided alternative sources of economic power, security, aid, ideology, as well as institutional platforms to the autocrats and emerging autocrats, without imposing political

\footnotetext{
${ }^{4}$ Autocratization is defined by Lührmann and Lindberg [42] as "substantial de-facto decline of core institutional requirements for electoral democracy". It is a move away from democracy and includes autocratization processes taking place in both democracies and autocracies. Authoritarian resilience denotes the resilience or durability of authoritarian political system that is able to resist or adapt to democratic demands.
} 
conditionality that favors liberal values. The pandemic has provided opportunities to consolidate their positions and promote their models worldwide.

The entrenchment of authoritarianism is first and foremost reflected by the durability of authoritarian regimes during the pandemic. To the disappointment of those seeking cracks in the authoritarian regimes hit hard by the pandemic, the autocrats around the world have largely survived the tests resulting from the pandemic. In particular, the resilience of communist regimes, such as China and Vietnam, has provided clear examples of entrenched authoritarianism during the pandemic. In the case of China, confronted with the worst health crisis faced by the Chinese Communist Party (CCP), the regime's capacity is questioned by many scholars and observers. Pei argues that the pandemic has shown the regime's lack of capacity in responding to the health crisis and exposed the fragility of Xi Jinping's strongman rule. The regime will be trapped in economic stagnation and increasing social unrest domestically and in great-power competition abroad. As a result, it will start to "unravel by fits and starts" [44]. This assessment is consistent with Pei's earlier diagnosis of the CCP's serious illnesses and regime decay, as well as other scholars' observation of China's "frozen" political system $[45,46]$. However, the evidence so far suggests that the regime has not only managed to survive the crisis but also boosted its legitimacy.

Early in the outbreak, China's failure to respond was perceived as a manifestation of the breakdown of top-down governance structures [47]. Chinese people were angry at the government's handling the crisis in its initial response. The authorities chose to withhold information about the virus from the public, punished doctors for "spreading rumors," and prioritized stability over transparency. When the situation erupted beyond control, the influx of photos, videos, blogs, and diaries on social media depicting the ordeals of Wuhan citizens ignited both anger and fear among the public. The CCP rushed to calm the public, started a massive machine of mobilization, and implemented extreme lockdown measures. Grassroots organizations were also mobilized by the state to enforce quarantines and lockdowns, provide essential services, and collect information and monitor citizens, greatly enhancing the state's capacity at political and social control [48]. The state soon regained control of the situation, although life was far from being back to normal.

The shock caused by the pandemic was followed by the massive outbreaks in Europe and later the United States, overwhelming the capacity of one country after another. Chinese state media and social media produced vivid stories describing the disastrous responses in many Western democracies, especially their failures to copy China's "homework" for combating the coronavirus. It looked as though China was the only haven in the world and many Chinese people abroad struggled to find their way back home.

Both authoritarian and democratic countries have demonstrated mixed performances in responding to the pandemic. There are successful cases in democracies, such as that of South Korea, which presents an effective model for combating the coronavirus. There are also failed cases among autocracies, such as Iran, which struggled to contain the outbreak during its initial stage $[49,50]$. However, the failures of many democratic countries, especially the United States, to control the virus quickly and effectively helped reverse course in China and boost the CCP's domestic legitimacy. The comparison led many Chinese to believe that an authoritarian government is a better option for China, especially in times of crisis and during the rhetorical siege by the Western 
countries. The CCP gladly sells the idea of a better political system to its people through intensive nationwide propaganda, manipulation of social media, and spontaneous expression of national pride by its people. The success story of Vietnam which shares similar political-economic model with China further contributes to the discourse of a superior political system. In a survey conducted in April, researchers asked citizens to rate their countries' performance in dealing with the pandemic. China ranked highest among 23 countries, with a score of 85 out of 100, followed by Vietnam (77). In the rating of the political leaders' response to the crisis, both countries (China, 86 out of 100; Vietnam, 82) outpaced major Western countries, including New Zealand (67), Germany (35), the United States (32), the United Kingdom (30), and Italy (25) [51]. Another report based on online surveys finds that trust in the Chinese government was as high as $95 \%$ in April [52].

Beyond China, other authoritarian leaders exploited the crisis to further tighten control over their people. In Russia, which closely monitored its neighbor's techdriven model of control, the pandemic provided an opportunity for Russian authorities to develop new surveillance capabilities equipped with facial-recognition and geolocation tracking systems [53]. In Iran, the hard-liners leveraged the massive pressures from the pandemic to consolidate power. Members of the Revolutionary Guards were dispatched to enforce strict quarantine measures, while ramping up efforts to monitor and silence citizens on the basis of "national security" [54-56]. Moreover, conservatives capitalized on the missteps made by the moderate, civilian-led government. They launched campaigns to undermine it, portraying the Revolutionary Guards as "the guardian of public health and the champion of the fight against the invisible enemy" [57].

Coupled with authoritarian resilience, a wave of autocratization has surged around the world during the pandemic. In Hungary, a country already experiencing rapid erosion of freedoms and democratic norms in recent years, Prime Minister Viktor Orbán secured an indefinite state of emergency that allows him to rule by decree. Journalists can be jailed for up to five years for spreading misinformation that hinders the government's response to the pandemic [58]. Similarly, in the name of maintaining order and combatting disinformation during the pandemic, extraordinary emergency powers were invoked in both Thailand and the Philippines. These powers allowed the Thai authorities to censor or shut down media and the latter to imprison those accused of spreading false information on social media and other platforms [59, 60].

By late April, more than 84 countries had enacted emergency laws to give executives more power to handle the coronavirus [61]. Previous researches already found that states of emergency often associate with a heightened risk of autocratization [62]. Before the pandemic, more than one-third of the world's population already lived in autocratizing countries. Moreover, for the first time since 2001, the majority of countries in the world are autocracies (92 in total) [63]. The pandemic has reinforced anti-democratic trends, with 48 countries at high risk of pandemic backsliding and 34 others at medium risk [64]. While the urgency and presence of the coronavirus will eventually dissipate, the effect of the authoritarian measures and the institutional legacies will likely remain, influencing both domestic politics and foreign policies.

Rather than witnessing "the end point of mankind's ideological evolution and the universalization of Western liberal democracy as the final form of human government" [11], the world is now seeing a regime landscape mixed with thriving authoritarianism 
and democracy. To complicate the matters further, the challengers to the current order have exploited the pandemic to assert their political systems and ideologies, which are seen as incompatible with the Western standards and values. Ikenberry asserts that neither China nor Russia has a model that is appealing to the rest of world [10]. However, because of the ideological divergence, authoritarian political-economic models built by these two countries are increasingly welcomed by sitting dictators and emerging autocrats. China and Russia have already become alternative providers of goods such as developmental assistance and military security, which used to be monopolized by major Western powers [23]. Now, they are using such leverages to rival the liberal order led by the United States, building "parallel structures of global governance that are dominated by authoritarian states and that compete with older, more liberal structures" [65].

In comparison to Russia, China has maintained more extensive institutional networks. China has created, expanded, and led important international institutions (such as the Asian Infrastructure Investment Bank), regional forums (the Forum for ChinaAfrica Cooperation), security organizations (the Shanghai Cooperation Organisation), and infrastructure investment projects (the Belt and Road Initiative). These institutions have become the cornerstones of its alternative political-economic model. In this model, the powerful and ambitious patron provides alternative sources of economic power, security, aid, ideology, as well as institutional platforms for the dictators and emerging autocrats, without imposing political conditionality that favors liberal values.

The pandemic allows these challengers to consolidate their positions and promote their political-economic models globally. In the case of China, it has sought to build a "health silk road" by sending medical teams and resources to numerous countries around the world. According to a report released by China's State Council Information Office, the country had offered or provided assistance to 150 countries and 4 international organizations as of June [66]. Major Western powers have widely criticized these efforts for their intention to capitalize on the pandemic and project China's influence globally. But China has won many hearts in the region where it has projected its economic and diplomatic influence through the Belt and Road Initiative in recent years. Countries that welcome China's growing influence include major autocratizing countries in Central and Eastern Europe, including Serbia, Hungary and the Czech Republic $[67,68]$. As a result, China can utilize its reciprocating relations with the receivers of medical goods and to garner additional support for its authoritarian political-economic model vis-à-vis the Western liberal model. Moreover, the exacerbation of nationalism in both democracies and autocracies further reinforces the consolidation of authoritarianism and authoritarian political-economic models during the pandemic.

\section{The Exacerbation of Nationalism}

Besides the challenge brought by the entrenchment of authoritarianism, the second challenge to current order stems from the exacerbation of nationalism. One of the underlying tensions of the current order exists between states seeking to assert their agency against the seemingly inexorable and homogenizing forces of globalization promoted by the liberal order. States refuse to be hollowed out by the globalizing forces and seek to assert their authority and legitimacy both within their territorial boundaries and in transnational processes. Nationalism has been a tool for modern states to 
legitimize their power at home and position themselves in the international arena. Besides its linkage to language and symbolism, nationalism is "a sociopolitical movement and an ideology of the nation" [69]. The pandemic provides fertile ground for nationalism to thrive in both democratic and authoritarian countries, as states reclaim their place and authority left by the retreat of globalizing forces. With help from nationalist and populist politicians, nationalism has blended with populism and authoritarianism and become stronger in both democratic and authoritarian hosts.

Confronted with the pandemic, many countries rushed to fend for themselves instead of joining together in multilateral efforts. State leaders worldwide unilaterally closed borders, restricted incoming travelers, grappled with solutions to meet their own soaring demands for medical supplies, and prepared to fix their damaged economies. States have reasserted their roles in responding to crises, guarding their sovereignty, and managing their own economies in the uncertain times, while the globalizing forces promoted by the current order are in the retreat. The self-serving calculations of national interests, in both political and economic spheres, have dominated many leaders' thinking since the outbreak of the pandemic and are likely to continue influencing policymaking in the post-pandemic struggle for recovery. The exacerbation of nationalism has eroded the popularity and authority of international institutions that buttress the principle of multilateralism and the seemly unstoppable forces of globalization promoted by the current order. It also pushes states to make choices that are most aligned with their national interests, from both material and ideological perspectives.

As Walt argues, "The pandemic will strengthen the state and reinforce nationalism" [7]. Bieber observes that even before the pandemic, exclusionary nationalism mixed with far-right politics and populism had already overshadowed major countries around the world. The pandemic reinforces nationalism in several important ways: a "marriage" between nationalism and authoritarianism, bias against others (including ethnic minorities and other marginalized groups) presumed to be associated with the pandemic, and the rise of deglobalization and anti-globalization [70]. These changes will likely reinforce existing nationalistic dynamics. These dynamics are evident during the pandemic at both state and society levels, as well as in both democratic and autocratic settings, as exemplified by the developments in the United States and China. Both countries have been involved in escalated "narrative battle" powered by nationalism [71].

In the United States, controversial labels, from the "Chinese Virus" to the "Kung Flu", were disseminated by President Trump as state leaders tried to find a scapegoat to blame for their own failures in responding to the pandemic. Even after the Administration wasted nearly two months responding to the crisis, many politicians were quick to defend Trump: "We don’t blame Trump, we blame China." Senator Lindsey Graham claimed that the Chinese government was responsible for all American deaths [72]. Only a few days later, the U.S. intelligence and national security officials said that the U.S. government was exploring the possibility that the coronavirus leaked from a lab in Wuhan [73]. Trump and the Secretary of State Mike Pompeo soon joined the chorus. They ignored the assessments made by many scientists and weaponized the coronavirus for political purpose. Both the Republican Party and the Democratic Party continued to blame China in an attempt to maximize their appeal to the voters and increase their odds of winning the 2020 election [74]. 
While the state leaders in the US were pandering to a nationalist base, xenophobic sentiment surged across the country. Within just four weeks (March 19-April 15), at least 1497 incidents of coronavirus-related discrimination targeting Chinese and other groups of Asian origins were reported in the United States. These incidents included verbal harassment, refusal of services, and even physical assault [75]. The Pew Research Center also found that negative views of China had risen to its highest point since the center started collecting data on Americans' views of China in 2005. About two-thirds $(66 \%)$ of American adults had a negative view of the country, a significant increase of 20 percentage points since Trump took office [76].

In China, nationalist strategies were also used at the state level. Early in the outbreak, the United States was blamed by China for its failure to provide sincere and substantive support toward China and for its overaction by raising its travel advisory level, bringing American citizens back, and blocking Chinese visitors. Later, the U.S. military was accused of intentionally spreading the virus in Wuhan, a theory promoted by Zhao Lijian, the spokesperson for China's Ministry of Foreign Affairs [77]. Moreover, the Ministry of Foreign Affairs announced its decision to expel American journalists working for The New York Times, The Wall Street Journal and The Washington Post, further fueling nationalist sentiment in China.

Likewise, the Chinese people's views of the United States drastically declined during the pandemic. Before the United States stepped up its efforts to shift the blame toward China, a survey by the Eurasia Group Foundation (February 15-March 3) found that China had witnessed the starkest decline among ten countries in their views toward the United States and American democracy. Favorable views of the United States decreased by nearly 20 percent as negative views increased by $11 \%$, compared to a 2019 report. Positive views of American democracy also declined by $15 \%$. About half of the respondents believed that the United States had made the world a worse place in the past 20 years [78]. An article published by a Chinese nationalist tabloid reported that Chinese people had seen the harm of U.S. hegemony and the darker side of democracy [79].

Politicians from both sides are playing a dangerous game by exploiting the nationalistic feelings in their respective societies to serve their own political agendas. Both sides have politicized the coronavirus and related scientific researches, further rousing animosity between the two countries. Beyond these two cases, many other nationalist and populist leaders around the world have sought to decry globalization and "others". The pandemic has given them the weapon they need. While Trump proclaimed on Twitter, "We need the wall more than ever!", France's rightist National Rally party's leader Le Pen blamed "the religion of borderlessness" for the virus outbreak. During the pandemic, state leaders and political parties in Hungary, India, Germany, Italy, and Spain have targeted ethnic minorities and other marginalized groups [67, 80-83]. Foreign workers and F1 students were the latest victims of current U.S. administration's populist and nationalist strategies [84, 85].

In the last decade, the world has witnessed the rise of nationalist and populist leaders in national and subnational politics throughout many regions [86-88]. The pandemic enables these leaders to rally their supporters and attack what they see as the illusion of solidarity between nations and the failure of international institutions, including the European Union and the World Health Organization (WHO). Moreover, states' recalculations of national interests are likely to reinforce their appeals because the 
pandemic has exposed the risk and vulnerability of global dependency regarding the supply chains and strategic resources. As a result, the pandemic will likely prompt a renationalization of production and transform global integration to a more limited form that is oriented toward regional and bilateral engagements [89].

Even in Europe, the region that serves as "the proof that human society was becoming transnational, transcending its national stage and moving towards a global community", confidence in globalization has declined. As we witness the "universal reversion to nationalist policies and defense of particularistic national interests at the expense of transnational solidarity", international institutions are more likely to suffer from the pandemic [90]. The pandemic has given "a political gift for nativist nationalists and protectionists" and will have long-term impact on many aspects of globalization, including the free movement of people and goods [91]. States are able to reclaim their place and assert their authority and legitimacy within their territorial boundaries and in transnational processes. As politicians in both democracies and autocracies exploit nationalism to serve their political agendas during the pandemic, they continue to deepen the divisions and tensions between countries, hinder multilateral cooperation, and contribute to the fragmentation of the existing international order.

The exacerbation of nationalism not only chips away the authority and legitimacy of established Western-dominated international institutions but also pushes states to make choices that are most aligned with their national interests, from both material and ideological perspectives. Their material and ideological preferences may converge with the alternative models proposed and promoted by the challengers of the current order. Challengers like China offer alternative sources of economic power, security, aid, ideology, and institutional platforms. During the pandemic, the goods on the list are extended to include medical supplies. This menu is especially attractive to state leaders who put national interest before the "Western doctrines" or seek for economic opportunity or breakthrough.

Hungary - a member state of the EU - is one of the cases that are highly receptive to China's offers. Hungary was the first European country to sign up for China's Belt and Road Initiative (BRI). It is also an active participant in the ChinaCEEC (Central and Eastern European Countries) summit $(17+1$ format) that helps China establish its foothold in the EU's backyard. As stated by Hungarian Prime Minister Viktor Orbán, China's BRI is "fully in harmony" with Hungary's national interest and "offers the right response to challenges in a changing world order". Hungary is ready to further cooperate with China for economic opportunities and reject "all outside ideological pressure" [92]. During the pandemic, Orbán and other ministers played down EU assistance and lashed out at those who criticized the government's autocratizing moves. As Foreign Minister Peter Szijjarto said in Parliament: "All of Europe, including western Europe, is always extraordinarily critical and often ready to educate and lecture about the essence of democracy, (but) everyone is standing in line in China for the products needed for health protection [68]." The offer of alternative resources and goods, coupled with the absence of political conditionality that favors liberal values, is increasingly popular among the autocrats and emerging autocrats. As a result, China continues to extend its networks and expand international space for its model. In the process of doing so, China has faced resistance from the dominant Western powers, but also successfully garnered more support around the world. 


\section{The Renewed Great Power Competition}

The exacerbation of nationalism and the entrenchment of authoritarianism has laid the new ground for major actors, including the retreating global leader (the United States), the weakening coalition (the European Union), and the rising but besieged challenger (China), to engage in a renewed great power competition in the pandemic era. The myth proliferated by the proponents of U.S.-led liberal order assumes that the order is cohesive, forged over seven decades by Western solidarity and a shared sense of purpose and righteousness [38]. Under strong U.S. leadership, a group of Western powers with common goals and shared commitment to preserve liberal values, norms, principles and institutions has been committed to sustaining and defending the current liberal international order. However, the perceived cohesiveness of this order was challenged during the pandemic, as the United States further retreated from its role as the leader of the order and the solidarity among the EU members states was seriously undermined. In the meantime, China had tried to fill in the gap left by the internal division and fragmentation within the West.

Since Trump assumed office, the United States has withdrawn from many multilateral agreements and international organizations. It continues to assert America's own interests while disregarding the interests of others, including its allies. Trump has continued his predecessor's trend towards global retrenchment and run on a platform that suggests "a much narrower definition of American interests and a lessening of the burdens of American global leadership" [29]. The pandemic further reveals Trump's lack of interest in carrying the burdens of global leadership and in strengthening existing alliances and institutions. The United States has been absent in leading global efforts to fight the coronavirus. After blaming China's mishandling of the pandemic, the United States found another target to blame for its own failures in handling the crisis. It announced in May that it would halt funding for the WHO and terminate the relationship. It formally started withdrawing from the organization in July. The U.S.centric moves have dealt serious blows to the institutional pillars of the current liberal order and undermined the principle of multilateralism. Moreover, the pandemic has further tarnished its global image as the primary defender and unifier of the liberal world. As Tellis notes, the pandemic threatens the U.S. position in deadly ways. It has battered the U.S. economy and weakened its economic power; discredited its state competency in times of crisis; and corroded the U.S.-led international order, as the country is questioned by allies for failing to protect shared norms, rules and institutions and to ensure shared prosperity in the face of strategic competitors [93]. The pandemic may be the straw that breaks the camel's back.

The stronghold of the liberal international order has not fared well during the pandemic. The EU was seriously questioned for its slow and bureaucratic responses to the outbreak in the region. When Italy begged its European partners for masks and equipment, the latter responded by closing their borders and hoarding medical supplies for domestic use [94]. The ethos of "every country for itself" not only spread in countries led by nationalist leaders but also other member states of the EU [95]. Solidarity among nations quickly devolved into a game of survival in which each country grappled with its own solutions. Some observers have already cast doubts on the future of the EU [96]. According to a report released in May, 52\% of the respondents were not satisfied with the measures the EU had taken against the 
pandemic. Among all member states, dissatisfaction was particularly high among southern European countries. In Italy and Spain, only $23 \%$ and $26 \%$ of respondents, respectively, were satisfied with the EU's response. Fewer than a quarter of the respondents in Greece (22\%), Spain (21\%), and Italy (16\%) were satisfied with the solidarity between EU member states in fighting the pandemic [97].

While the foremost defenders of the current order seem to be in disarray and the tensions within the Western club are exposed in the pandemic, China sees a chance to increase its global influence, by filling in the gap left by the West's internal division and fragmentation. China already revealed its ambition in playing a more prominent role in international affairs and potentially transforming the global order by the Belt and Road Initiative, the Asian Infrastructure Investment Bank, and other alternative institutions. The political-economic model that China has been building is oriented toward increasing economic and diplomatic influence without exporting or imposing its preference for a political system. As stated in a white paper that focuses on China's relation with the world, China "does not 'import' foreign models, nor 'export' the Chinese model, and will never require other countries to replicate its practices" [41]. Nonetheless, China has been actively promoting its image and influence globally. Europe is one region in which China has intensively projected its influence in recent years. During the pandemic, "health silk road" was being taunted by Chinese state media as exemplifying a different kind of global leadership than Trump's America [98]. The public discontent with the EU, coupled with a distrust of the United States, has provided the opportunity for China to promote its global image, especially in countries hit hard by the coronavirus or in urgent need of help, such as Italy, Spain, Serbia, and elsewhere.

As China makes inroads into the areas traditionally dominated by the West, it has encountered strong resistance from major powers. Several combined factors are pushing China to a besieged position, both politically and economically, in the global arena. These factors include the dispute over the poor quality of medical supplies sent by China; the pressure on China to be more transparent and take the responsibility for the pandemic; the call for China to compensate other countries for damages caused by the coronavirus; the strain and ramification of economic downturns in major Western countries; and the possible relocation of industries for important strategic resources back to the West.

Before the pandemic, based on the reassessment of China's economic and political power and its ambitions to be a leading global power, the EU had labeled China as "a systemic rival promoting alternative models of governance" [99]. The pandemic has forced the EU to reassess the challenges from China. European leaders have become increasingly concerned about the issues of supply chains and telecoms security, risks associated with closer Sino-Russian coordination, and China's moves to advance its ideological agenda that is hostile to European values [100].

While the EU tries to find the middle ground in dealing with China, the United States is increasingly hostile toward China's rise. According to a report released by the White House in May, China's growing economic, political, and military power "harms vital American interests and undermines the sovereignty and dignity of countries and individuals around the world." In response to China's economic, ideological, and security challenges, the United States has adopted a competitive approach guided by "a return to principled realism," seeking to protect American interests and advance American influence [101]. 
The pandemic has not only widened the division between the Western powers, but also deepened the crevasse between China and the West [102]. According to the report presented by the Ministry of State Security to top Beijing leaders in May, the global anti-China sentiment is at its highest level since the 1989 Tiananmen Square Incident. The report warned that this sentiment could fuel resistance to China's Belt and Road Initiative and exasperate the security situations in Asia. The growing hostility between China and the United States could lead to armed confrontation [103]. China is eager to defend its authoritarian political system. It also relies on nationalism to boost domestic legitimacy and now sees the chance to expand its global influence. Thus, China may move further toward transforming the international order as it gradually recuperates its economic strength from the destruction brought by the pandemic.

Since President Xi Jinping came to power, he has largely abandoned Deng Xiaoping's Tao Guang Yang Hui strategy (conceal one's ability and bide one's time) and pushed for "major country diplomacy" (Da Guo Wai Jiao). His perception of China's status in the international order also departs from previous leaders' views that positioned China at the periphery or semi-periphery of the existing Western-dominated order [104: 18]. Xi pointed out "in explicit terms" that China is "closer than ever to the center of the global stage" and "closer than ever to fulfilling the Chinese dream of national renewal" [105]. Creating and expanding alternative international institutions, regional forums, security organizations, and infrastructure investment projects - the cornerstones of the alternative political-economic model - are helping to push China to the center of the global stage.

To deal with the complex and ever-changing international environment, $\mathrm{Xi}$ consistently emphasizes the importance of "bottom-line thinking," which means always being prepared for the worst-case scenario, be it crisis or conflict. In a meeting with national legislators from the army and armed police force during the annual "Two Sessions" in May, Xi stated that the pandemic has profoundly affected on the world's situation as well as China's security and development. As a result, he emphasized, "The Chinese military must stick to bottom-line thinking, comprehensively strengthen combat training, respond effectively and in a timely way to sophisticated scenarios and firmly safeguard national sovereignty, security, development interests and its strategic stability" [106]. In recent years, China has expanded its list of core interests to include the political system, sovereignty and territorial integrity, security, and development interests [107]. If the international environment became too hostile, China would never allow its core interests to be undermined. The imposition of national security law in Hong Kong reflects this logic.

The resurgence of great power competition, both in material and ideological senses, has joined the other two forces - the exacerbation of nationalism and the entrenchment of authoritarianism. As China and the Western powers compete with each other at different fronts, the existing international order has become more divisive, fragmented, and confrontational. The more China feels cornered by the increasingly hostile West, particularly the United States, the more likely it will be to pursue more assertive policies regarding its political-economic model. China will likely use its institutional and ideological leverages to expand more space for its model and reconfigure the current order based on its interests and ideology. 


\section{Implication and Conclusion}

This paper examines how the pandemic could transform the liberal international order. The pandemic has generated immense pressure on the existing order that is rife with tensions. The principal foundations of the current order - the liberal ideology, the principle of multilateralism, and a group of defenders with shared commitment to preserve liberal values, norms, principles and institutions - are shaken by several powerful forces during the pandemic. The entrenchment of authoritarianism has, on the one hand, contributed to the erosion of liberal ideology. On the other hand, it has consolidated the alternative political-economic models led by China and other authoritarian challengers. The exacerbation of nationalism, by blending with populism and authoritarianism, further undermines the popularity and authority of international institutions that buttress the principle of multilateralism and the globalizing forces promoted by the liberal order. It also pushes states to make choices that are most aligned with their national interests, from both material and ideological perspectives. Moreover, the pandemic has intensified internal divisions and fragmentation within the West. In the meantime, it has accelerated great power competition between China and the West as China seeks to fill in the gap left by dominant Western powers. The tensions that exist in the current liberal order and the sources of change during the pandemic may reconfigure the liberal international order into an order that is more fragmented and confrontational.

China, seen as a powerful challenger to the order, has played mixed roles in the process of reconfiguring the liberal international order. First, along with other challengers, China challenges the mythologized liberal international order and exposes the contradictions in the dominant Western model which often needs to reconcile its proclaimed liberal values with illiberal behaviors. China also has proposed and promoted alternative authoritarian political-economic model that is hybrid in its forms, containing both the elements of authoritarian control and coercion, as well as cooperation and rule. The defining feature of this model is authoritarian. But it also incorporates the more liberal elements of the existing international order. China has essentially turned the international arena into a market of competing models, challenging the monopoly enjoyed by Western powers for decades. In comparison to Russia and other potential challengers, China is more ambitious and successful in promoting its model in this market and improving its global image. During the pandemic, China not only builds an image of strong authoritarian power but also an active provider of public goods that is ready to cooperate with other countries and contribute to the international community.

Second, China continues to utilize traditional Western-dominated international institutions to benefit from the current order, showing its support for the current order. As Acharya notes, "It is ironic that while the founders of liberal order are retreating (at least temporarily), and the order itself is fraying at the edges, some of the powers, especially China, that are supposed to challenge it are offering support" [108]. But in the meantime, over the past few years, China has invested significant resources in building alternative international institutions, regional forums, security organizations, and infrastructure investment projects. Both strategies help to diversify China's choices and maximize its shares in and potential rewards from the international order. Moreover, by creating dense networks for 
international social relations, China socializes with other states, strengthens their connection, and presents them with attractive alternative choices. As a result, states are encouraged to want things including access to sources of economic power, security, aid, ideology, and institutional platforms. As a result, state leaders who put national interest first or seek for these resources are drawn closer to China's model. The offer of alternative resources and goods, coupled with the absence of political conditionality that favors liberal values, is increasingly popular in the world with mixed regime landscape. The shock brought by the pandemic has provided ample opportunities for China to extend its networks and expand international space for its model.

The mixed roles played by China reflect the complex dynamics in the existing international order. Instead of viewing the current international order solely by the idealized lens of the liberal world, it would be more informative to treat the existing order as a multiplex international order with competing politicaleconomic models. On the one hand, as China continues to integrate into the global market and international community, China has proposed and promoted an alternative model that asserts authoritarian control but also incorporates more liberal elements that encourage international trade and cooperation and support multilateral institutions and related rules. On the other hand, the Western-dominated model proclaims liberal values but has engaged in violence and coercion in its attempts to order the world, especially when it comes to America's behavior in the world. The failed projects of "social engineering" [37] that attempted to transform the world by violence reveal the contradictions in the Western model. Both China and the United States are deeply embedded in the current international order. While their models have major differences, they also overlap with each other in at least two areas: the liberal components of the authoritarian model, and the illiberal components of the liberal model.

Driven by the convergence of material interests and ideologies, states may locate themselves closer to the core of one model or move toward the competing model. Major powers that lead the different models may attempt to draw other states closer by attracting them to their "way of life" or forcing them to integrate into their models. The competition between these powers could escalate and potentially lead to conflict and confrontation. Moreover, the creation and extension of international social networks by institutional platforms or linkages can facilitate socialization between states and encourage state leaders to make certain choices. The external shock caused by the pandemic has intensified the competition between these different models as well as their major actors. It also has triggered the reshuffling of different actors' positions in the international order. The Western-dominated model is confronted with internal division and fragmentation but intends to preserve its share in the current order. China has vigorously launched a global initiative to attract more support for its model. Fierce competition will continue after the pandemic as they attempt to expand their space in the international arena. The West needs to rethink about its efforts in "chasing idealistic chimeras" [37] globally and acknowledge the limit of this endeavor and the coexistence of competing models in the international order. 


\section{References}

1. Staniland, Paul. 2018. Misreading the 'Liberal order': Why we need new thinking in American foreign policy. July 29. Available at https:/www.lawfareblog.com/misreading-liberal-order-why-we-need-newthinking-american-foreign-policy.

2. Walt, Stephen M. 2018. Why I Didn't sign up to defend the international order? August 1. Foreign Policy Available at https://foreignpolicy.com/2018/08/01/why-i-didnt-sign-up-to-defend-theinternational-order.

3. Acharya, Amitav. 2016. The future of global governance: Fragmentation may be inevitable and creative. Global Governance 22: 453-460.

4. Weaver, Catherine. 2008. Hypocrisy trap: The World Bank and the poverty of reform. Princeton: Princeton University Press.

5. Woods, Ngaire. 2010. Global governance after the financial crisis: A new multilateralism or the last gasp of the great powers? Global Policy 1: 51-63.

6. Stephen, Matthew D. 2017. Emerging powers and emerging trends in global governance. Global Governance 23: 483-502.

7. Allen, John et al. 2020. How the world will look after the coronavirus pandemic. March 20. Foreign Policy. Available at https://foreignpolicy.com/2020/03/20/world-order-after-coroanvirus-pandemic/.

8. Lake, David A., and Peter Gourevitch. 2018. Hundreds of scholars have signed a statement defending the international institutions that trump has attacked. August 14. Washington Post Monkey Cage. Available at https://www.washingtonpost.com/news/monkey-cage/wp/2018/08/14/hundreds-ofscholars-have-signed-a-statement-defending-the-international-institutions-that-trump-has-attacked/? utm_term=.2aa635665788.

9. Ikenberry, G. John. 2011. Liberal leviathan: The origins, crisis, and transformation of the American world order. Princeton: Princeton University Press.

10. Ikenberry, G. John. 2018. The end of liberal international order? International Affairs 94: 7-23.

11. Fukuyama, Francis. 1989. The end of history? The National Interest 16: 3-18.

12. Haass, Richard N. 2018. Liberal World Order: R.I.P. March 21. Project Syndicate. Available at https:// www.project-syndicate.org/commentary/end-of-liberal-world-order-by-richard-n\%2D\%2Dhaass-2018-03.

13. Ruggie, John Gerard. 1993. Multilateralism: The anatomy of an institution. In Multilateralism Matters: The Theory and Praxis of An Institutional Form, eds. John Gerard Ruggie. New York: Columbia University Press.

14. Hasenclever, Andreas, Peter Mayer, and Volker Rittberger. 1997. Theories of international regimes. Cambridge: Cambridge University Press.

15. Acharya, Amitav. 2006. Multilateralism, sovereignty and normative change in world politics. In Multilateralism under challenge? Power, international order, and structural change, eds. Edward Newman, Ramesh Thakur and John Tirman. Tokyo: United Nations University press.

16. Keohane, Robert O., and Lisa Martin. 1995. The promise of Institutionalist theory. International Security 20: 39-51.

17. Gilpin, Robert. 1981. War and change in world politics. Cambridge: Cambridge University Press.

18. Mearsheimer, John J. 1994/1995. The false promise of international institutions. International Security 19: 5-49.

19. Waltz, Kenneth N. 2000. Structural realism after the cold war. International Security 25: 5-41.

20. Gearan, Anne, and David Nakamura. 2018. Trump delivers defiant defense of his foreign policy approach to skeptical U.N. audience. September 25. The Washington Post. Available at https://www. washingtonpost.com/politics/at-united-nations-trump-rejects-constraints-imposed-by-other-nationssays-us-will-act-to-counter-global-control/2018/09/25/1a5f8b22-c0c9-11e8-be77-516336a26305_story. html.

21. Patrick, Stewart M. 2017. Trump and World Order: The Return of Self-Help. Foreign Affairs 96, No. 2 (March/April): 52-57.

22. Suri, Jeremy. 2017. How Trump's executive orders could set America Back 70 years. January 27. Atlantic. Available at https://www.theatlantic.com/politics/archive/2017/01/trumps-executive-orderswill-set-america-back-70-years/514730/.

23. Cooley, Alexander, and Daniel Nexon. 2020a. Exit from hegemony: The unraveling of the American global order. Oxford: Oxford University Press.

24. Bew, John. 2017. The eclipse of the west. January 31. New Statesman. Available at https://www. newstatesman.com/world/2017/01/eclipse-west.

25. Doyle, Michael W. 2017. New Global Disorder. Dissent Magazine 64: 123-128. 
26. Stephens, Bret. 2015. America in retreat: The new isolationism and the coming global disorder. New York: Sentinel.

27. Nicolas, Françoise. 2016. China and the global economic order: A discreet yet undeniable contestation. China Perspectives 2: 7-14.

28. Nye, Joseph S. 2017. Will the liberal order survive: The history of an idea. Foreign Affairs 96, No 1 (January/February): 10-16.

29. Kagan, Robert. 2017. The twilight of the Liberal world order. In Brookings Big Ideas for America, eds. Michael E. O’Hanlon. Washington D.C.: Brookings Institution Press.

30. Porter, Patrick. 2018. A world imagined: Nostalgia and Liberal order. Cato Institute Policy Analysis 843: 1-24.

31. Rosenau, James N. 1992. Governance, order, and change in world politics. In Governance without Government: Order and Change in World Politics, eds. James N. Rosenau, and Ernst-Otto Czempiel. Cambridge: Cambridge University Press.

32. Buzan, Bary. 1993. From international system to international society: Structural realism and regime theory meet the English school. International Organization 47: 327-352.

33. Allison, Graham. 2018. The myth of the Liberal order: From historical accident to conventional wisdom. Foreign Affairs 97: 10-19.

34. Wendt, Alexander. 1999. Social theory of international politics. Cambridge: Cambridge University Press.

35. Finnemore, Martha. 1996. National Interests in international society. Ithaca: Cornell University Press.

36. Strange, Susan. 1987. The persistent myth of lost hegemony. International Organization 41: 551-574.

37. Walt, Stephen M. 2020. There's no such thing as good Liberal hegemony. April 20. Foreign Policy. Available at https://foreignpolicy.com/2020/04/21/theres-no-such-thing-as-good-liberal-hegemony/.

38. Barnett, Michael N. 2019. The end of a Liberal international order that never existed. April 16. The Global. Available at https://theglobal.blog/2019/04/16/the-end-of-a-liberal-international-order-thatnever-existed/.

39. Hobson, John M. 2012. The Eurocentric conception of world politics: Western international theory, 1760-2010. Cambridge: Cambridge University Press.

40. Acharya, Amitav. 2014. The end of American world order. Cambridge: Polity.

41. China's State Council Information Office. 2019. China and the World in the New Era. September 27. Xinhua. Available at http://english.www.gov.cn/archive/whitepaper/201909/27/content_ WS5d8d80f9c6d0bcf8c4c142ef.html.

42. Lührmann, Anna, and Staffan I. Lindberg. 2019. "A third wave of autocratization is here: What is new about it?" Democratization: 1-19.

43. Pierson, Paul. 2000. "Increasing Returns, Path Dependence, and the Study of Politics." The American Political Science Review 94, No. 2 (June): 251-267.

44. Pei, Minxin. 2020. China's coming upheaval: Competition, the coronavirus, and the weakness of xi Jinping. Foreign Affairs 99.

45. Gallagher, Mary E. 2020. Carl Minzner, the end of an era: How China's authoritarian revival is undermining its rise. Journal of Chinese Political Science 25: 519-520.

46. Pei, Minxin. 2016. China's crony capitalism: The dynamics of regime decay. Cambridge: Harvard University Press.

47. Ronkin, Noa. 2020. Coronavirus crisis exposes fundamental tension in governing China, says Stanford sociologist and China expert Xueguang Zhou. Feb 3. Freeman Spogli Instsitute for international studies. Available at fsi.stanford.edu/news/coronavirus-crisis-exposes-fundamental-tension-governing-chinasays-stanford-sociologist-and.

48. Rithmire, Meg. 2020. Daniel C. Mattingly. The Art of Political Control in China. Journal of Chinese Political Science 25: 513-514.

49. Kangarlou, Tara, and Joseph Hincks. 2020. 'People Are Dying Left and Right.' Inside Iran's Struggle to Contain Its Coronavirus Outbreak. March 17. Time. Available at time.com/5804706/iran-coronavirus/.

50. Kleinfeld, Rachel. 2020. Do authoritarian or democratic countries handle pandemics better? March 31. Carnegie endowment for international peace. Available at carnegieendowment.org/2020/03/31/doauthoritarian-or-democratic-countries-handle-pandemics-better-pub-81404.

51. Blackbox Research. 2020. The world in crisis: A global public opinion survey across 23 countries. May 6. Available at https://knowledge.blackbox.com.sg/world-in-crisis-COVID19.

52. Edelman Trust Barometer. 2020. Trust and the Covid-19 pandemic. May 5. Available at https://www. edelman.com/research/trust-2020-spring-update.

53. Ilyushina, Mary. 2020. How Russia is using authoritarian tech to curb coronavirus. March 29. CNN. Available at www.cnn.com/2020/03/29/europe/russia-coronavirus-authoritarian-tech-intl/index.html. 
54. Fassihi, Farnaz, and David D. Kirkpatrick. 2020. Iran's coronavirus response: Pride, paranoia, secrecy, Chaos. March 3. The New York Times. Available at www.nytimes.com/2020/03/03/world/middleeast/ coronavirus-iran.html.

55. Gambrell, Jon. 2020. Iran's revolutionary guard seeks absolution in virus fight. March 7. The Associated Press. Available at apnews.com/f7e6ea36b5c48118409f33c5795dfa17.

56. Toossi, Sina. 2020. Iran's hard-liners are sitting pretty. April 16. Foreign Affairs. Available at www. foreignaffairs.com/articles/iran/2020-04-16/irans-hard-liners-are-sitting-pretty.

57. Tabatabai, Ariane M. 2020. Iran's revolutionary guards play politics with the coronavirus. April 29. Foreign Affairs. Available at www.foreignaffairs.com/articles/iran/2020-04-29/irans-revolutionaryguards-play-politics-coronavirus.

58. Walker, Shaun, and Jennifer Rankin. 2020. Hungary passes law that will let Orbán rule by decree. March 30. The Guardian. Available at www.theguardian.com/world/2020/mar/30/hungary-jail-forcoronavirus-misinformation-viktor-orban.

59. Peck, Grant, and Preeyapa T. Khunsong. 2020. Some leaders use pandemic to sharpen tools against critics. April 16. The Associated Press. Available at apnews.com/a4566b26badabcc30c0da02436af0e07.

60. Wongcha-um, Panu, and Kay Johnson. 2020. Thai leader to invoke emergency powers as virus infections climb. March 24. Reuters. Available at uk.reuters.com/article/us-health-coronavirusthailand-emergency/thai-leader-to-invoke-emergency-powers-as-virus-infections-climbidUKKBN21B0RV.

61. The Economist. 2020. A pandemic of power grabs: Autocrats see opportunity in disaster. April 23. Available at www.economist.com/leaders/2020/04/23/autocrats-see-opportunity-in-disaster.

62. Lührmann, Anna, and Bryan Rooney. 2020. Autocratization by decree: States of emergency and democratic decline. V-Dem Working Paper 85: 1-38.

63. Lührmann, Anna et al. 2020. V-Dem democracy report 2020: Autocratization surges-resistance grows. V-Dem institute. Available at www.v-dem.net/media/filer_public/f0/5d/f05d46d8-626f-4b20-8e4e53d4b134bfcb/democracy_report_2020_low.pdf.

64. Lührmann, Anna, Amanda B. Edgell, and Seraphine F. Maerz. 2020. Pandemic backsliding: Does Covid-19 put democracy at risk? V-Dem Policy Brief 23: 1-4.

65. Cooley, Alexander, and Daniel Nexon. 2020b. How hegemony ends: The unraveling of American power. Foreign Affairs 99.

66. China's State Council Information Office. 2020. Fighting Covid-19: China in Action. June 7. Xinhua. Available at www.xinhuanet.com/english/2020-06/07/c_139120424.htm?bsh_bid=5517099546.

67. Mairs, Sally. 2020. Serbia sets the stage for Beijing's mask diplomacy. April 2. AFP. Available at www. euractiv.com/section/china/news/serbia-sets-the-stage-for-beijings-mask-diplomacy/.

68. Stojanovic, Dusan. 2020. China's 'mask diplomacy' wins support in Eastern Europe. April 14. AP. Available at apnews.com/76dff4b113e82d85716262895909f151.

69. Smith, Anthony D. 2010. Nationalism: Theory, ideology, history. Cambridge: Polity.

70. Bieber, Florian. 2020. Global nationalism in times of the COVID-19 pandemic. Nationalities Papers Special Issue: 1-13.

71. Jaworsky, B.N., and Runya Qiaoan. 2020. The politics of blaming: The narrative Battle between China and the US over COVID-19. Journal of Chinese Political Science: 1-21.

72. Richardson, Reed. 2020. 'We Don’t blame trump, we blame China'. April 9. Mediaite. Available at www.mediaite.com/news/we-dont-blame-trump-we-blame-china-lindsey-graham-claims-chinesegovernment-responsible-for-16000-american-deaths/.

73. Campbell, Josh, Kylie Atwood and Evan Perez. 2020. US explores possibility that coronavirus spread started in Chinese lab, not a market. April 15. CNN. Available at www.cnn.com/2020/04/15/politics/usintelligence-virus-started-chinese-lab/index.html.

74. Martin, Jonathan, and Maggie Haberman. 2020. A key G.O.P. strategy: Blame China. But trump Goes off message. April 18. The New York Times. Available at www.nytimes.com/2020/04/18/us/politics/ trump-china-virus.html.

75. Jeung, Russel, and Kai Nham. 2020. Incidents of coronavirus-related discrimination. A report for A3PCON and CAA. April 23. Available at http://www.asianpacificpolicyandplanningcouncil.org/wpcontent/uploads/STOP_AAPI_HATE_MONTHLY_REPORT_4_23_20.pdf.

76. Devlin, Kat, Laura Silver, and Christine Huang. 2020. U.S. views of China increasingly negative amid coronavirus outbreak. April 21. Pew Research center. Available at https://www.pewresearch.org/global/ 2020/04/21/u-s-views-of-china-increasingly-negative-amid-coronavirus-outbreak/.

77. Meyers, Steven Lee. 2020. China Spins Tale That the U.S. Army Started the Coronavirus Epidemic. March 13. The New York Times. Available at www.nytimes.com/2020/03/13/world/asia/coronaviruschina-conspiracy-theory.html. 
78. Hannah, Mark, and Caroline Gray. 2020. Global views of American democracy: Implications for coronavirus and beyond. April. Eurasia Group Foundation. Available at https://egfound.org/wpcontent/uploads/2020/03/Global-Views-of-American-Democracy-EGF.pdf.

79. Li, Qingqing. 2020. Inept COVID-19 fight dims Chinese view on US system. April 14. Global Times. Available at www.globaltimes.cn/content/1185546.shtml.

80. Cliffe, Jerymy. 2020. How populist leaders exploit pandemics. March 18. NewStatesman. Available at www.newstatesman.com/world/2020/03/how-populist-leaders-exploit-pandemics.

81. Michalopoulos, Sarantis, and Daniel Eck, Zoran Radosavljevic. Le pen spreads fake news over EU role on coronavirus. Feb 27. EURACTIV Network. Available at www.euractiv.com/section/politics/news/ le-pen-spreads-fake-news-over-eu-role-on-coronavirus/.

82. Slater, Joanna, and Niha Masih. 2020. As the world looks for coronavirus scapegoats, Muslims are blamed in India. April 22. The Washington Post. Available at www.washingtonpost.com/world/asia pacific/as-world-looks-for-coronavirus-scapegoats-india-pins-blame-on-muslims/2020/04/22/ 3cb43430-7f3f-11ea-84c2-0792d8591911_story.html.

83. Tondo, Lorenzo. 2020. Salvini attacks Italy PM over coronavirus and links to rescue ship. Feb 24. The Guardian. Available at www.theguardian.com/world/2020/feb/24/salvini-attacks-italy-pm-overcoronavirus-and-links-to-rescue-ship.

84. BBC. 2020. H-1B among visas hit by Trump's new foreign worker freeze. June 23. Available at www. bbc.com/news/business-53145317.

85. Jordan, Miriam, Zolan Kanno-Youngs, and Dan Levin. 2020. Trump visa rules seen as way to pressure colleges on reopening. July 7. The New York Times. Available at www.nytimes.com/2020/07/07/us/ student-visas-coronavirus.html.

86. Karl, Terry Lynn. 2019. Extreme inequality and state capture: The crisis of Liberal democracy in the United States. Chinese Political Science Review 4 (2): 149-163.

87. Lai, B.H., and N.F. Martini. 2020. Nationalism and its effects on attitudes about trade, cooperation, and immigration. Fudan Journal of the Humanities and Social Sciences: 1-22.

88. Roberts, K.M. 2019. Crises of representation and populist challenges to Liberal democracy. Chinese Political Science Review 4: 188-199.

89. Fontaine, Richard. 2020. Globalization will look very different after the coronavirus pandemic. April 17. Foreign Policy. Available at https://foreignpolicy.com/2020/04/17/globalization-trade-war-aftercoronavirus-pandemic/.

90. Greenfield, Liah. 2020. COVID-19, nationalism, and the politics of crisis: A scholarly exchange. Nations and Nationalism. Available at https://onlinelibrary.wiley.com/doi/epdf/10.1111/nana.12644.

91. Legrain, Phillippe. 2020. The coronavirus is killing globalization as we know it. March 12. Foreign Policy. Available at https://foreignpolicy.com/2020/03/12/coronavirus-killing-globalizationnationalism-protectionism-trump/.

92. Hungary Today. 2019. Orbán in China: 'Accept that different political systems can be more successful'. April 29. Available at https:/hungarytoday.hu/orban-in-china-accept-that-different-political-systemscan-be-more-successful/.

93. Tellis, Ashley J. 2020. Covid 19 knocks on American hegemony. The National Bureau of Asia Research The New Normal in Asia: 1-10.

94. Laurent, Lionel. 2020. The EU's big pandemic failure Isn't about money. April 14. Bloomberg. Available at www.bloomberg.com/opinion/articles/2020-04-14/coronavirus-the-eu-s-failure-isn-tabout-money-but-health-policy.

95. Baczynska, Gabriela, and Luke Baker. 2020. EU clutches at bazooka to stop members going it alone on coronavirus. March 16. Reuters. Available at uk.reuters.com/article/us-health-coronavirus-eucoordination/eu-clutches-at-bazooka-to-stop-members-going-it-alone-on-coronavirusidUKKBN2133F5.

96. Rankin, Jennifer. 2020. Coronavirus could be final straw for EU, European experts warn. April 1. The Guardian. Available at www.theguardian.com/world/2020/apr/01/coronavirus-could-be-final-straw-foreu-european-experts-warn.

97. Kantar. 2020. Public opinion in the EU in time of coronavirus crisis. April. European Parliament. Available at www.europarl.europa.eu/at-your-service/en/be-heard/eurobarometer/public-opinion-in-theeu-in-time-of-coronavirus-crisis.

98. The Economist. 2020. Thanking big brother: China's post-covid propaganda push. April 16. Available at www.economist.com/china/2020/04/16/chinas-post-covid-propaganda-push.

99. European Commission. 2019. EU-China - A strategic outlook. March 12. Available at https://ec.europa. eu/commission/sites/beta-political/files/communication-eu-china-a-strategic-outlook.pdf. 
100. Small, Andrew. 2020. The meaning of systemic rivalry: Europe and China beyond the pandemic. European Council on Foreign Relations Policy Brief 321: 1-19.

101. The White House. 2020. United States Strategic Approach to the People's Republic of China. May 26. Available at www.whitehouse.gov/articles/united-states-strategic-approach-to-the-peoples-republic-ofchina/.

102. Haenle, Paul, and Lucas Tcheyan. 2020. How the world is responding to a changing China. June 10. Carnegie Endowment for International Peace. Available at https://carnegieendowment.org/2020/06/10/ how-world-is-responding-to-changing-china-pub-82039.

103. Hirschberg, Peter. 2020. Exclusive: Internal Chinese report warns Beijing faces Tiananmen-like global backlash over virus. May 4. Reuters. Available at www.reuters.com/article/us-health-coronavirus-chinasentiment-ex/exclusive-internal-chinese-report-warns-beijing-faces-tiananmen-like-global-backlashover-virus-idUSKBN22G19C.

104. Wang, Jianwei. 2019. Xi Jinping's 'major country diplomacy:' A paradigm shift? Journal of Contemporary China 28: 15-30.

105. Yang, Jiechi. 2017. Study and implement general secretary xi Jinping's thought on diplomacy in a deepgoing way and keep writing new chapters of major-country diplomacy with distinctive Chinese features. July 17. China's Ministry of Foreign Affairs. Available at https://www.fmprc.gov.cn/mfa_eng/wjdt_ 665385/zyjh_665391/t1478497.shtml.

106. Zhao, Lei. 2020. Xi urges military combat readiness. May 27. China Daily. Available at https://www. chinadaily.com.cn/a/202005/27/WS5ecda00ba310a8b241158a71.html.

107. Zhou, Jinghao. 2019. China's Core interests and dilemma in foreign policy practice. Pacific Focus XXXIV 34: 31-54.

108. Acharya, Amitav. 2017. After Liberal hegemony: The advent of a multiplex world order. September. Ethics and International Affairs. Available at https://www.ethicsandinternationalaffairs.org/2017/ multiplex-world-order/.

Qingming Huang is a PhD Candidate at the Department of Political Science at the University of Florida. His research interests include ethnicity and nationalism, state building, authoritarian politics, and communism and post-communism. 